ISSN 1112-9867

\title{
CALCULATION OF DOSE DISTRIBUTION ON RHIZOPHORA SPP SOY PROTEIN PHANTOM AT 6 MV PHOTON BEAM ENERGY USING MONTE CARLO METHOD
}

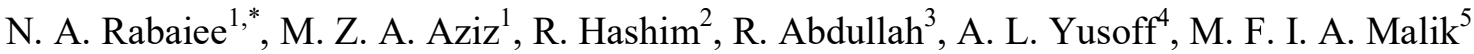 \\ and A. A. Tajuddin 6 \\ ${ }^{1}$ Cluster of Oncological and Radiological Science, Advanced Medical and Dental Institute, \\ UniversitiSains Malaysia, Bertam, Pulau Pinang, Malaysia \\ ${ }^{2}$ Division of Bioresearch, Paper and Coating, School of Industrial Technology, \\ UniversitiSains Malaysia, Minden, Pulau Pinang, Malaysia \\ ${ }^{3}$ School of Health Science, UniversitiSains Malaysia Health Campus, KubangKerian, \\ Kelantan, Malaysia \\ ${ }^{4}$ Department of Nuclear Medicine, Radiotherapy and Oncology, Hospital UniversitiSains \\ Malaysia, KubangKerian, Kelantan, Malaysia \\ ${ }^{5}$ Science and Engineering Research Center, Universiti Sains Malaysia Engineering Campus, \\ Nibong Tebal Pulau Pinang, Malaysia \\ ${ }^{6}$ School of Physics, UniversitiSains Malaysia, Minden, Pulau Pinang, Malaysia
}

Published online: 10 November 2017

\begin{abstract}
Some of the commercial solid phantoms were unable to provide a good simulation to water at low and high energy ranges. A potential phantom from Malaysian mangrove wood family, Rhizophoraspp was fabricated with addition of Soy Protein. An Electron Gamma Shower (EGSnrc) code was used to evaluate the dose distribution on Rhizophoraspp Soy Protein phantom at $6 \mathrm{MV}$ photon beam energy.
\end{abstract}

Author Correspondence, e-mail: norainrabaiee@mail.com doi: http://dx.doi.org/10.4314/jfas.v9i6s.20 
The result of the Rhizophoraspp Soy Protein phantom was then compared with the water phantom and the solid water phantom. This study showed that the uncertainty between Rhizophoraspp Soy Protein phantom and the water phantom and the solid water phantom is less than $8 \%$ at certain depth. These comparable results have demonstrated the potential of the Rhizophoraspp Soy Protein phantom as another option for solid phantom in dosimetry purposes.

Keywords: mangrove wood; solid water phantom; water equivalent phantom; EGSnrc; depth dose.

\section{INTRODUCTION}

Water is the best medium recommended for dosimetry at high-energy photon and electron beams. Water utilized as reference medium since the measurement was approximately closed to the estimation of radiation absorption and scattering from human soft tissue. However, it is not always common sense to perform dosimetric measurements in a water phantom because it is hard to deal at hectic department [1]. Therefore, solid water equivalent phantoms such as solid water, perspex, polystyrene and proprietary materials have become a preference mostly for clinical dosimetry [2].

Studies on Rhizophoraspp as a water equivalent material have been conducted by several authors by found that the Rhizophoraspp has a favourable composition with water [2-3]. Comparison between Rhizophoraspp and water properties was further conducted at diagnostic energy ranges by few researchers [4-5]. In 2001, Rhizophoraspp properties were evaluated in high energy photons and electron beams [6]. Based on their study, they found out that the dose discrepancy between Rhizophoraspp and water was within 2.4 and $2.6 \%$ for electron and photon beam respectively.

The binderlessRhizophoraspp particleboard that was lacks in stability was then upgraded by adding adhesive to improve the dimensional stability as aparticleboard. This indication improved its dimensional stability as well its morphology structure. The mass attenuation results also showed that there was no significant difference between Rhizophoraspp with soy protein at energies between 15.7 to $25.3 \mathrm{keV}$ [7].

A Monte Carlo user-friendly code, Electron Gamma Shower (EGSnrc) code as an advanced 
and reliable technique was used to perform radiation dose calculation. Monte Carlo is widely used for treatment planning in photon and electron beams [8]. This technique is proved to provide accuracy between 2-3\% in various phantom setup [9-11]. It uses a random numbers and probability statistics to model a complex physical system calculation. Monte Carlo techniques are performed by simulating millions of particles through matter. A larger number of simulation particles (particle histories) will increase the accuracy in predicting dose distribution. Although the Monte Carlo techniques provide high accuracy in treatment planning, computational time initially was prohibitively long for clinical setting. However, improvements in computing power, technology and approximation method have reduced computing time to overcome this problem.

In this current study, a model of Primus Linear Accelerator (LINAC) treatment head was constructed using the EGSnrc code. A $6 \mathrm{MV}$ photon beam energy model was validated using the actual Primus LINAC beam measurement data before simulation was conducted in Rhizophoraspp Soy Protein phantom. The dose distribution results of the Rhizophoraspp Soy Protein phantom was then compared with the water phantom and the commercial solid water phantom.

\section{MATERIALS AND METHODS}

\subsection{Fabrication of Rhizophoraspp Soy Protein Phantom}

The middle part of Rhizophorasppwas harvested from the mangrove forest Taiping, Perak, Malaysia. The trunk was sawn and reduced into wood chips based on the previous study [12]. The chips were then grounded into small wood dust into the size of 50-104 $\mu \mathrm{m}$ based on the available horizontal sieve machine. The particleboard with dimension $30 \times 30 \times 0.5 \mathrm{~cm}^{3}$ was fabricated with target density, $1 \mathrm{~g} / \mathrm{cm}^{3}$. Cold pressed were apply on the wood dust of Rhizophoraspp and Soy Protein at approximately $200 \mathrm{~kg} / \mathrm{cm}^{3}$ for $3 \mathrm{~min}$ followed with hot pressed at $200{ }^{\circ} \mathrm{C}$ temperature for $20 \mathrm{~min}$ and $250 \mathrm{~kg} / \mathrm{cm}^{3}$.

\subsection{Monte Carlo Modelling and Validation}

The geometrical model of the Siemens Primus LINAC was set up according to the information provided by the manufacturer, as shown in Fig. 1. Every details of component module, including density, material composition, position, and direction was necessary to 
build an accurate treatment head of Siemens Primus LINAC.

The 6 MV Siemens Primus LINAC used in this study comprises of a target, primary collimator, scattering foil, ionization chamber, mirror, secondary collimator, movable jaws and reticle. The phase space files were generated for $10 \times 10 \mathrm{~cm}^{2}$ field sizes. These phase spaces contain all of the information (i.e., position, energy, direction and type) for each particle that exits the treatment head of the Linear Accelerator.

The phase space file was set to be $100 \mathrm{~cm}$ from the target. Parameters used to perform the phase space files were based on recommendation made previous author [13]. Electron cut-off energy (AE=ECUT) was set to $0.7 \mathrm{MeV}$, and photon cut-off energy (AP=PCUT) was set to $0.01 \mathrm{MeV}$. The simulation was performed using $2 \times 10^{8}$ particle histories. The number of particle histories was decided the number of primary electrons hitting the target.

A beam data processor (BEAMDP) was used to analyse the photon energy spectrum at the surface of the water phantom. BEAMDP used phase space data as the input and derived into spectral distribution and X-Y scatter. The same space phase was then applied as aninput file to simulate particle transport in the water phantom using DOSXYZnrc/EGSnrc code. A 3-dimensional (3D) water phantom with dimension of $28 \times 28 \times 30 \mathrm{~cm}^{3}$ was simulated with a source to surface distance $(\mathrm{SSD})$ set at $100 \mathrm{~cm}$. 


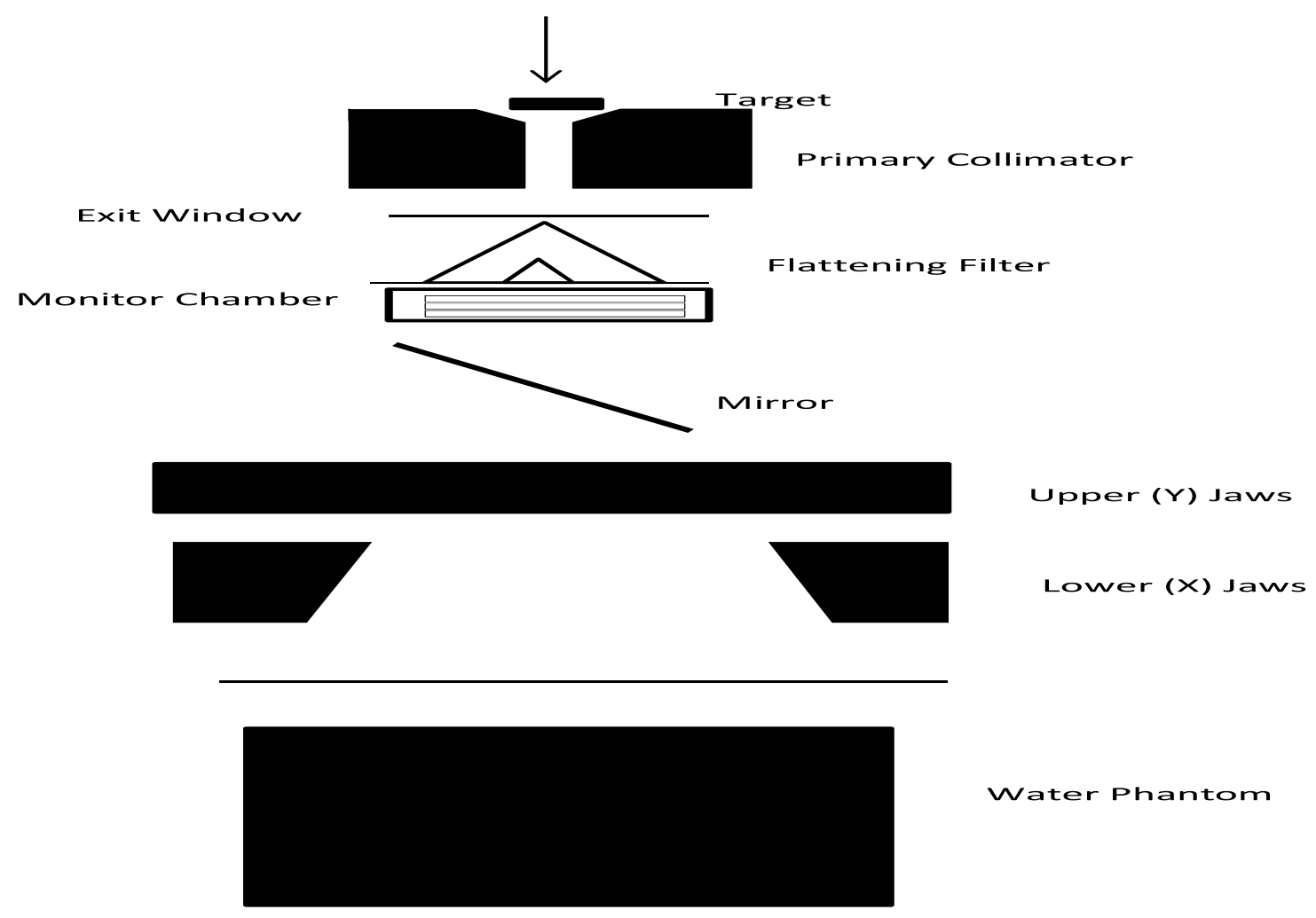

Fig.1. Schematic diagram of the Primus linear accelerator in EGSnrc/BEAmnrc code

\subsection{Calculation of Dose Distribution on Rhizophoraspp Soy Protein Phantom}

The RhizophorasppSoy Protein particleboard was scanned on the Computed Tomography (CT) Scanner using abdomen protocol; $120 \mathrm{kVp}$ with $3 \mathrm{~mm}$ slice thickness as in Fig. 2. An image from the CT scanner was in Digital imaging and communication in medicine (DICOM) format. DICOM format is the standard communication between different diagnostic and therapeutic modalities. However, CT phantom option on EGSnrc/DOSXYZnrc code allows calculation of dose distribution in *.egsphant file format. Thus, CTCreate was used converted the DICOM format from CT scanner into *.egsphant using process as proposed [14] using CTCREATE code.

The dose distribution of Rhizophoraspp Soy Protein particleboard was then compared with the dose distribution on the water phantom and solid water phantom. The dose error at each depth for the phantom was calculated using the equation below

$$
\text { Dose error }(\%)=\frac{\text { Dose at } R_{p}-\text { Dos at } S_{p}}{\text { Dose at } S_{p}} \times 100 \%
$$

whereRp is the Rhizophoraspp Soy Protein Phantom and Sp is the standard phantom; water 
phantom and solid water phantom.

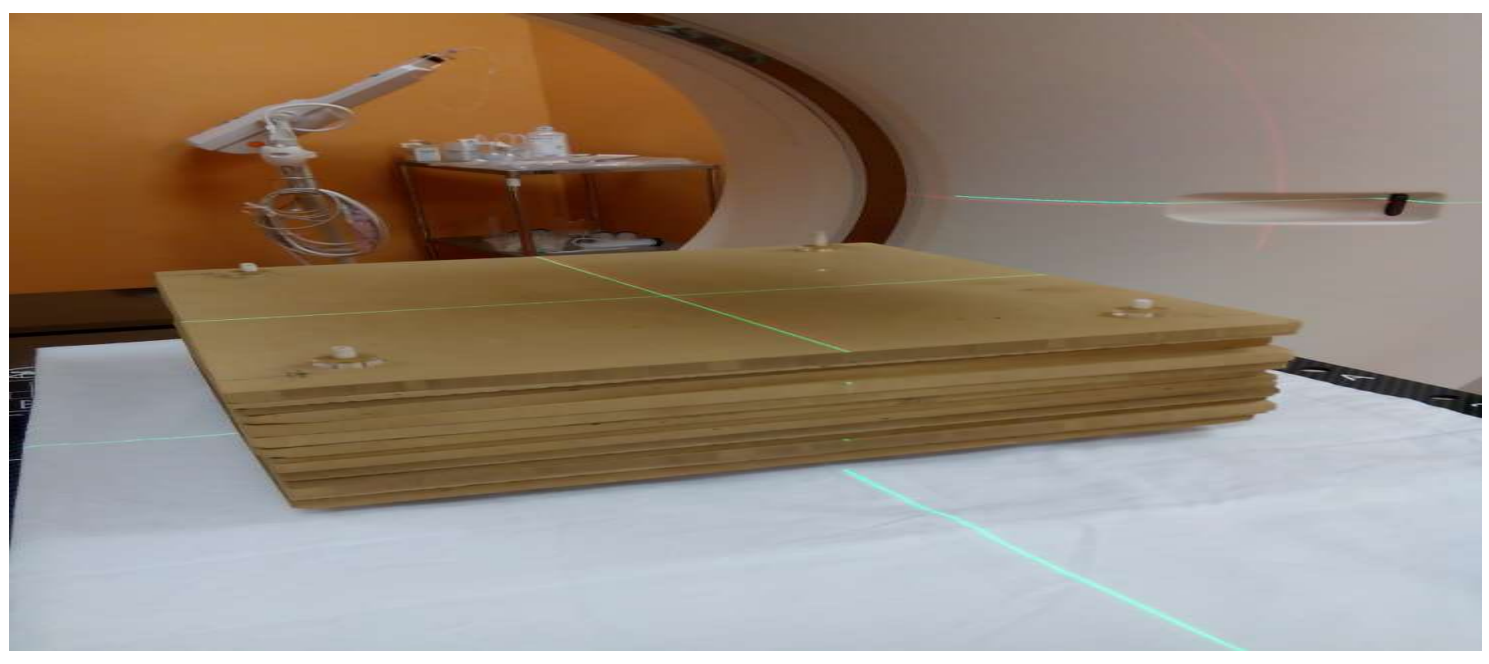

Fig.2.Rhizophoraspp Soy Protein phantom was scanned on CT scanner via abdomen protocol

\section{RESULTS AND DISCUSSION}

\subsection{Validation of Treatment Head Linear Accelerator}

Aprecise and validated model of the Primus LINAC was required to ensure that the Monte Carlo model was accurate for dose calculations. The X-Y scatter and energy spectral were calculated by BEAMDP utility from the phase space file at $\mathrm{SSD}=100 \mathrm{~cm}$.

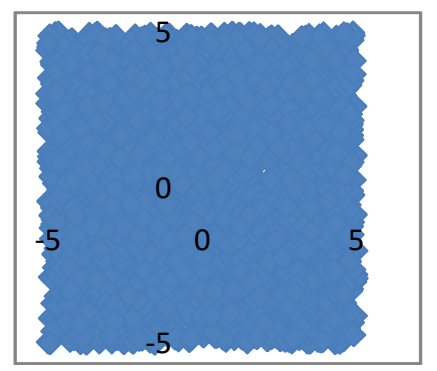

Fig.3. X-Y Scatter plots of the $6 \mathrm{MV}$ photon beam energy

Fig. 3 illustrates the X-Y scatter plots of the $6 \mathrm{MV}$ photon beam energy at $10 \times 10 \mathrm{~cm}^{2}$ field size. The jaws ( $\mathrm{X}$ and $\mathrm{Y}$ jaws) were open as expected. The jaws also functioned to collimate the beam very well to generate the accurate field sizes. Some scattered radiation was expected in the scatter plot due to the interaction that occurred between the electron beam and the accessories on the treatment head of the linear accelerator. 


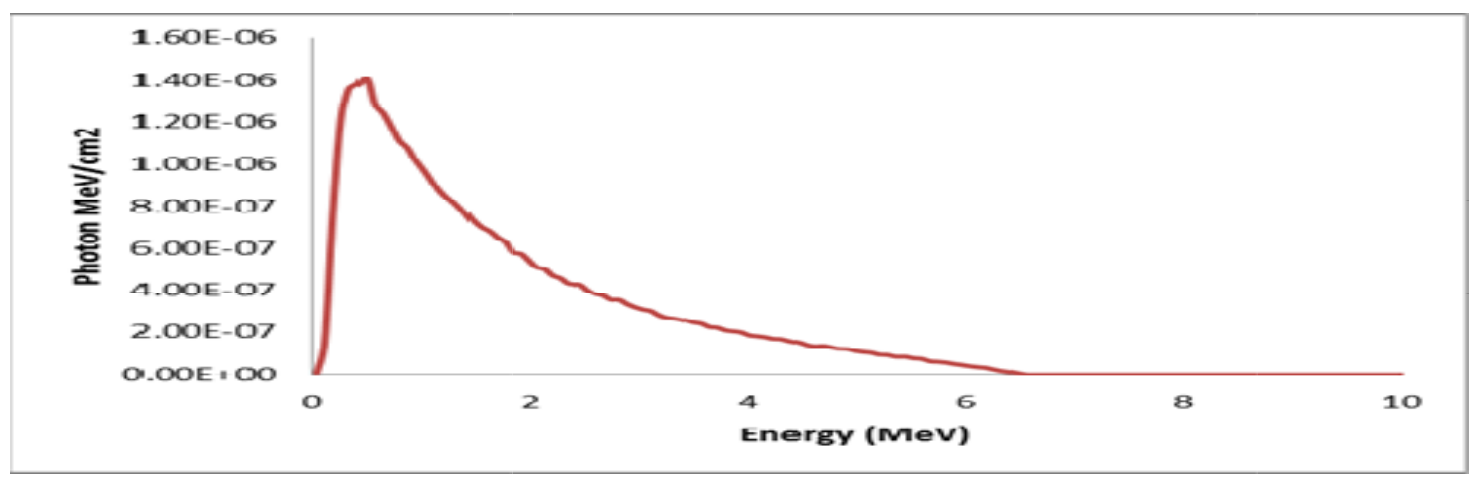

Fig.4. Energy spectrum for $6 \mathrm{MV}$ photon beam at 10x10 $\mathrm{cm} 2$ field size

Fig. 4 shows the energy spectrum of $6 \mathrm{MV}$ photon beam. The spectrum was measured at a distance of $100 \mathrm{~cm}$, where phase space was placed. Energy spectra are dependent on the accelerator tube and scattering foil [10]. As illustrated, the energy spectrum had one peak and the ended at $6 \mathrm{MeV}$ (6 MV photon mode) due to its initial kinetic energy. It was comparable with the previous researcher that uses the same energy on their study [15].

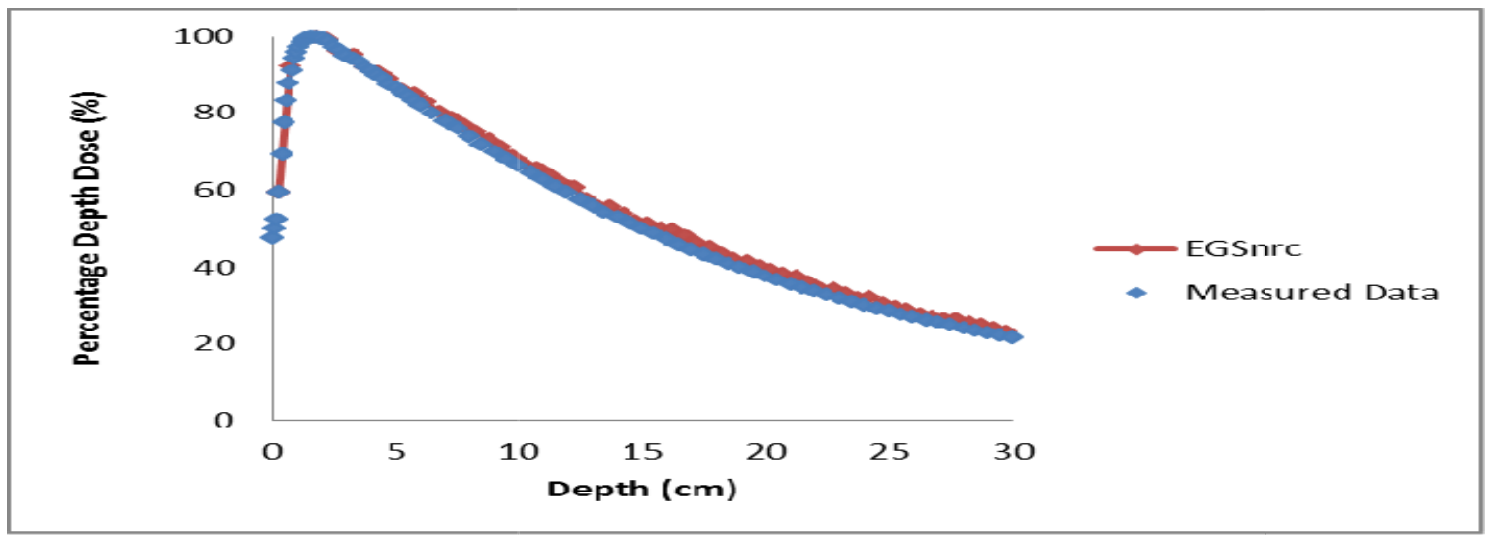

Fig.5. Comparison of dose along the central axis between Monte Carlo simulation and ion chamber measurement from linear accelerator in a water phantom

The dose along the central axis from the Monte Carlo simulation was then compared with the ion chamber measurement from the linear accelerator in a water phantom as shown in Fig. 5. The curves were normalised to depth at maximum dose. Generally, dose along the central axis is dependent on the initial kinetic energy as well as the energy distribution in material it is interacting. In this study, initial kinetic energy for the $6 \mathrm{MV}$ photon beam was set based on the information provided by the manufacturer.

The curves for the simulation Monte Carlo and measurement data were similar in shape with good agreement by having less than $2 \%$ percentage difference. These small differences 
between simulation and measurement data can be explained by the electron contamination that occurred when the electrons interacted with the phantom in the surface region [15].

Another possible reason from the observed discrepancy is because of statistical uncertainties of Monte Carlo method [16]. The number of histories is directly affecting the length of time to complete the calculation. It worked as important parameter to achieve a precise statistical. However, there is none of literature provide an exact number of particle history that was enough for simulation.

\subsection{Comparison Depth Dose on the Rhizophoraspp Soy Protein Phantom, the Water and the Solid Water phantom}

The MC calculation on depth dose of Rhizophoraspp Soy Protein particleboard, water phantom and solid water phantom were illustrated in Fig. 6. In Fig. 7 and 8, the dose error between the Rhizophoraspp Soy Protein, the water phantom and the solid water future detailed.

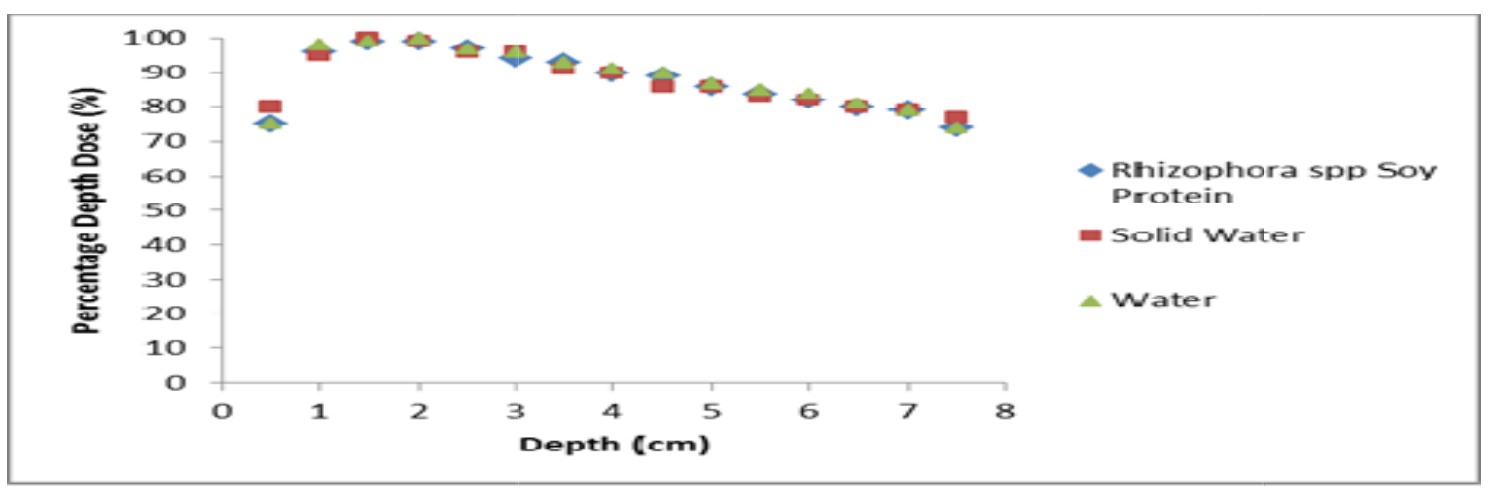

Fig.6. Monte Carlo dose calculation on depth dose of Rhizophoraspp Soy Protein phantom, water phantom and solid water phantom

The Monte Carlo calculated values of dose error for $6 \mathrm{MV}$ photon beams for Rhizophoraspp Soy Protein with water phantom is less than $2 \%$. The depth dose at the depth of maximum dose (Dmax), $1.5 \mathrm{~cm}$ was observed identical with the calculation in water phantom. However, the discrepancies remained within $2 \%$ between dmax and depth $7.5 \mathrm{~cm}$.

For the comparison of dose error between Rhizophoraspp Soy Protein particleboard and solid water phantom, the discrepancies is within $5 \%$. At the Dmax, the dose difference was $1 \%$ between the Rhizophoraspp Soy Protein phantom and the solid water phantom. 


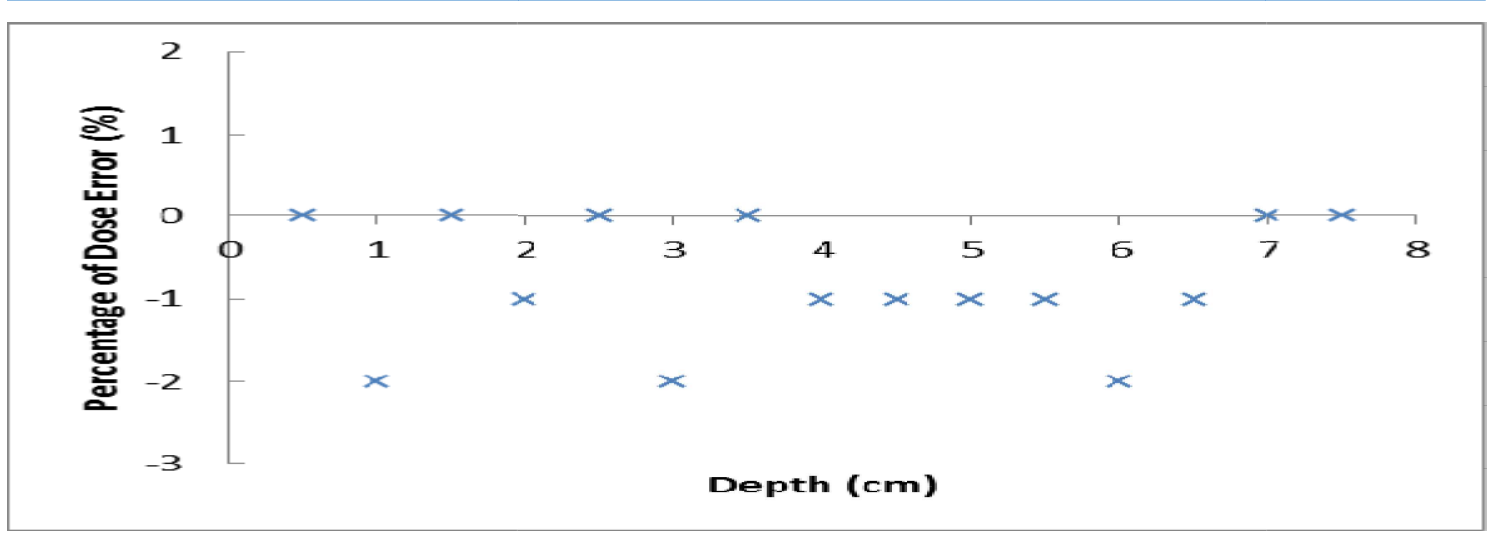

Fig.7. Dose error between Rhizophoraspp Soy Protein phantom and water phantom at certain depths

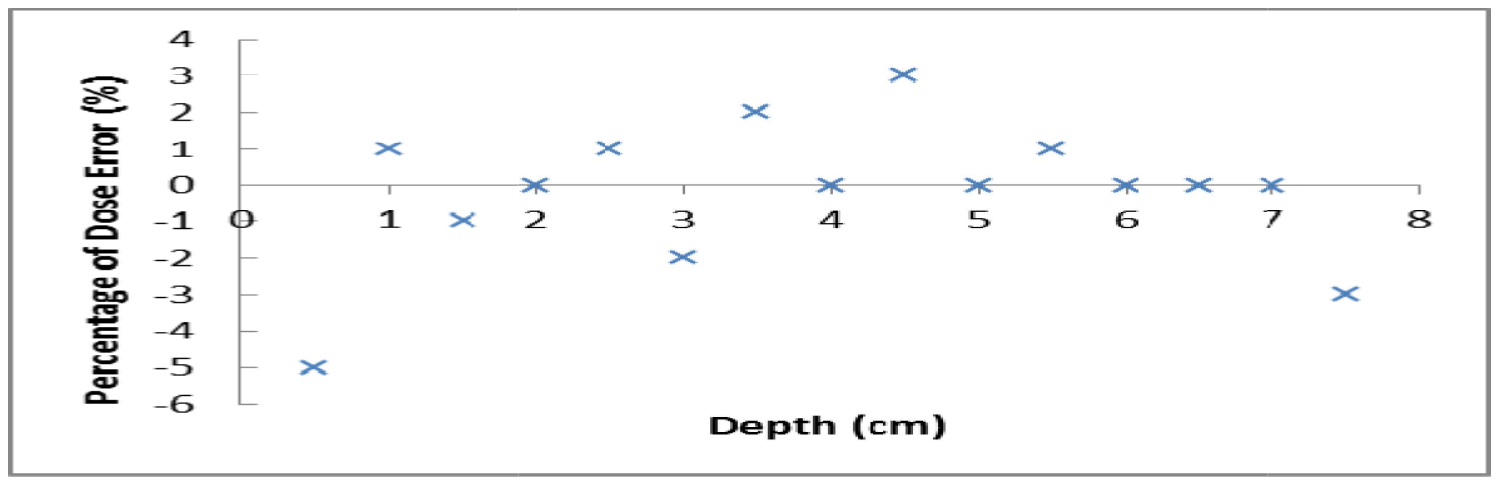

Fig.8. Dose error between Rhizophoraspp Soy Protein phantom and solid water phantom at certain depths

\section{CONCLUSION}

In this study, the performance of Rhizophoraspp Soy Protein phantom was verified using Monte Carlo method. The comparable results of Rhizophoraspp Soy Protein phantom with water and solid water phantom at high energy photon beams promising a new chapter of water equivalent materials with discrepancy of measurement less than $2 \%$. Thus, the Rhizophoraspp Soy Protein phantom can be potential dosimetric phantom in the near future.

\section{ACKNOWLEDGEMENTS}

The author would like to thank the Hospital UniversitiSains Malaysia, the Cluster of Oncological and Radiological Sciences, the Advanced Medical and Dental Institute Bertam and Science and Engineering ReaserchCenter. Appreciation also is extended to Siemens 
Healthcare for providing information about the Primus linear accelerator and the Ministry of Higher Education for funding under the Fundamental Research Grants Scheme 203/CIPPT/6711341.

\section{REFERENCES}

[1]Bradley DA, TajuddinAA, Sudin CW, Bauk S. Photon attenuation studies on tropical hardwoods. International Journal of Radiation Applications and Instrumentation. Part A: Applied Radiation and Isotopes, 1991, 42(80):771-773

[2] Khan F. M. The physics of radiation therapy. Philadelphia: Lippincott Williams and Wilkins, 2010

[3]Abuarra A, Bauk S, Hashim R, Kandaiya S, Tousi ET, Aldroobi K. Microstructure examination, elemental composition analysis of gum Arabic bonded Rhizophora spp. Particleboards and their potential as tissue equivalent material. International Journal of Chemical, Environmental and Biological Sciences, 2014, 2(1):71-75

[4]Shakhreet BZ, Bauk S, Tajuddin AA, Shukri A. Mass attenuation coefficients of natural Rhizophora spp. wood for X-rays in the 15.77-25.27 keV range. Radiation Protection Dosimetry, 2009, 135(1):47-53

[5] Marashdeh MW, Bauk S, Tajuddin AA, Hashim R. Measurement of mass attenuation coefficients of Rhizophora spp. binderless particleboards in the $16.59-25.26 \mathrm{keV}$ photon energy range and their density profile using x-ray computed tomography. Applied Radiation and Isotopes, 2012, 70(4):656-662

[6] Banjade DP, Tajuddin AA, Shukri A. A study of Rhizophoraspp wood phantom for dosimetric purposes using high-energy photon and electron beams. Applied Radiation and Isotopes, 2001, 55(3):297-302

[7]Rabaiee NA, Aziz MZ, Hashim R, Tajuddin AA, Malik MF. Potential of rhizophoraspp particleboard treated with soy flour as water equivalent material. JurnalTeknologi, 2015, $77(6): 7-11$

[8] Reynaert N, Van der Marck SC, Schaart DR, Van der Zee W, Van Vliet-Vroegindeweij C, Tomsej M, Jansen J, Heijmen B, Coghe MA, De Wagter C. Monte Carlo treatment planning for photon and electron beams. Radiation Physics and Chemistry, 2007, 76(4):643-686 
[9]Sardari D, Maleki R, Samavat H, Esmaeeli A. Measurement of depth-dose of linear accelerator and simulation by use of Geant 4 computer code. Reports of Practical Oncology and Radiotherapy, 2010, 15(3):64-68

[10]Reynaert N, Van der Marck S, Schaart D, Van der Zee W, Tomsej M, Van Vliet-Vroegindeweij C, Jansen J, Coghe M, De Wagter C, Heijmen B. Monte Carlo treatment planning: An introduction. Technical 2006, http://radiationdosimetry.org/files/documents/0000015/68-ncs-rapport-16-monte-carlo-treatm ent-planning.pdf

[11]Jabbari N, Hashemi-Malayeri B. Monte Carlo modeling of electron beams from a NEPTUN 10PC medical linear accelerator. Nukleonika, 2009, 54(4):233-238

[12] Marashdeh MW, Hashim R, Tajuddin AA, Bauk S, Sulaiman O. Effect of particle size on the characterization of binderless particleboard made from Rhizophora spp. Mangrove wood for use as phantom material. BioResources, 2011, 6(4):4028-4044

[13]Ding GX. Dose discrepancies between Monte Carlo calculations and measurements in the buildup region for a high-energy photon beam. Medical Physics, 2002, 29(11):2459-2463

[14] Walters BR, Kawrakow I, Rogers DW. DOSXYZnrcusers manual. NRCC Report PIRS-0794, 2013,https://nrc-cnrc.github.io/EGSnrc/doc/pirs794-dosxyznrc.pdf

[15] Aljamal M, Zakaria A. Monte Carlo modeling of a Siemens Primus 6 MV photon beam linear accelerator. Australian Journal of Basic and Applied Sciences, 2013, 7(10):340-346

[16] DeMarco JJ, Chetty IJ, Solberg TD. A Monte Carlo tutorial and the application for radiotherapy treatment planning. Medical Dosimetry, 2002, 27(1):43-50

\footnotetext{
How to cite this article:

Rabaiee N A, Aziz A M Z, Hashim R, Abdullah R, Yusoff A L, Malik A M F I, Tajuddin A A. Calculation of dose distribution on Rhizophoraspp soy protein phantom at $6 \mathrm{mv}$ photon beam energy using Monte Carlo method. J. Fundam. Appl. Sci., 2017, 9(6S), 246-256.
} 